\title{
Performance Optimization of an eCAR by Parametric Analysis
}

\author{
Banda Gururaj \\ Department of EEE, GPREC R\&D Center \\ Andhra Pradesh, India and JNT University Anantapur \\ Ananthapuramu, Andhra Pradesh, India \\ anilgururaj009@gprec.ac.in
}

\author{
Kolli Sri Gowri \\ Department of Electrical and Electronics Engineering \\ G. Pulla Reddy Engineering College (Autonomous) \\ Kurnool, Andhra Pradesh, India \\ gowrivasu.3@gmail.com
}

\begin{abstract}
In this paper a method for performance optimization of an electric Car (eCAR) is proposed based on acceleration rate, maximum speed, and tractive force. Since the total tractive force is exerted by propulsion motor alone, the driving performance of an eCAR depends on the power of the propulsion motor and its control. The proposed pre-sizing methodology depicts the optimum power of the propulsion motor, and for the optimized motor the impact of road dynamics, acceleration rate, change in mass, and gear ratio on the eCAR's drive range are analyzed. The proposed electric propulsion system is modeled and the performance characteristics are analyzed using MATLAB to validate the behavior of an eCAR propulsion.
\end{abstract}

Keywords-drive cycle; eCAR; propulsion system; road dynamics; mass; gear ratio and range

\section{INTRODUCTION}

In urban areas, there is a prodigious concern on intensifying air pollution caused by fossil fuels. Hence, the use of zero emission vehicles emerged as a need. Electric Vehicles (EVs) have been developed into battery electric vehicles (BEVs), hybrid electric vehicles (HEVs), plug-in hybrid electric vehicles (PHEVs), and fuel cell vehicles (FCVs), making a considerable impact in the automotive market. Nowadays, EVs accomplish the performance indices of traditional sport utility vehicles (SUVs). The EV eCAR is gaining more attention in the current automotive market being a zero emission vehicle offering higher energy efficiency, hushed operation and, frequent start-stop driving capability. The Government of India and its State Governments have initiated the "Smart City", Faster Adoption and Manufacture of (Hybrid and) Electric Vehicles (FAME-I \& FAME-II) schemes with thrust on providing "e-Mobility" for citizens. Authors in [1] discussed several aspects essential in creating an affluent EV market in India. Authors in [2] specified some considerations to determine the local and global environment impact of the autonomy electric transport in contrast with gasoline vehicles. Authors in [3] exemplified the real-world emissions and real driving behavior in real, cold, Nordic climates. Authors in [4] enlightened the transition of the automotive industry to electric mobility. Authors in [5] presented fuel economy and emissions comparison for diesel, gasoline, gasoline HEV, and BEV under the Environmental Protection Agency (EPA) drive cycles. Authors in [6] investigated the vision of introducing electric vehicles in real-life mobility, and their impression on the distribution grid. Authors in [7] researched the challenges and issues when EVs are charged from the grid. Authors in [8] proposed a method to examine energy efficiency, emissions, noise, and operational availability of city buses. Authors in [9] presented an online algorithm to regulate the energy consumption of BEVs during driving based on vehicle physiognomies, driving pattern, route map, traffic, and climate. Authors in [10] developed robust algorithms for range estimation of an EV and provided options for least energy use. Authors in [11] discussed the confines and abilities of the BEV and found scaling trends between the EPA driving range for one charge cycle and regimenting the battery capacity by weight of the vehicle. Authors in [12] formulated a multiobjective optimization problem to size the components of a split-transition vehicle based on engine maximum power rating, motor, battery, and final drive ratio.

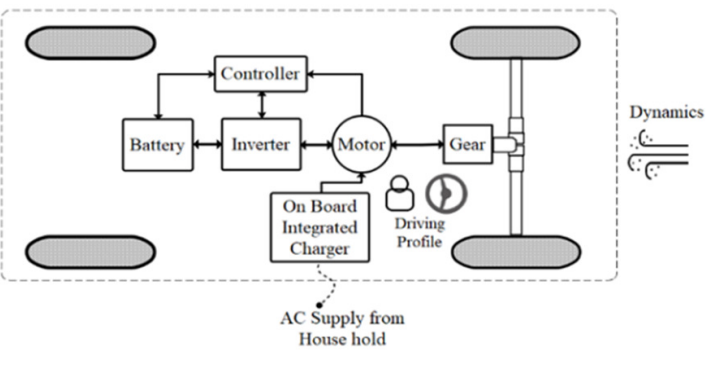

Fig. 1. Architecture of an eCAR

The architecture of an eCAR is shown in Figure 1. An eCAR propulsion system comprises of various components such as a stack of lithium ion batteries, a charging unit, propulsion motor, advanced power electronic converters, controller, mechanical transmission system, and auxiliary components. An eCAR is capable of smooth speed control, and provides high rates of acceleration/deceleration, high torque and low-speed hill climbing, low torque and high-speed cruising. Even though there have been advancements in technology, compact, economic and high energy efficient batteries are still in developing stage and are expensive. Batteries with integrated on-board and/or off-board charging facility, offering quick charge of less than 10 minutes and 
normal charging of 30-60 minutes through the utility grid have been introduced. An integrated on-board charger is more compact, with higher efficiency.

Authors in [13] evaluated a variety of DC-DC converter topologies for application in BEVs. Authors in [14] introduced an advanced on-board vehicular battery charger used for BEV application, which attains high power density by assimilating a bidirectional $\mathrm{AC} / \mathrm{DC}$ converter and a DC/DC converter. Authors in [15] described a procedure for estimating battery capacity, power, and cost. Authors in [16] investigated the effect of mileage accrual and fast charging on driving range and battery energy of a light-duty BEV. Authors in [17] developed a method to choose electric traction motors for BEVs. Authors in [18] elaborated the developments in design and optimization of propulsion motors for General Motor BEVs. Authors in [19] developed driving cycles based on empiric data from a large-scale field operational test for BEVs. Authors in [20] performed an analysis on real time Indian road drive cycles (IRDC) in terms of acceleration and deceleration rate, top speed, and average speed with road length.

In this paper, a method for performance optimization of an eCAR is proposed based on acceleration rate, maximum speed, and tractive force of the vehicle. Motor performance characteristics are analyzed in MATLAB.

\section{PROPOSED METHODOLOGY}

Consider the position of the eCAR shown in Figure 2 with the applied forces on the vehicle, where $M$ represents its mass in $\mathrm{kg}, \mathrm{V}$ represents the linear velocity in $\mathrm{m} / \mathrm{sec}$, g represents the gravitational acceleration in $\mathrm{N} / \mathrm{kg}$, h represents the height of the vehicle from center to ground level, and $\alpha$ represents the gradient in degrees. Thus, acceleration is computed for the given speed and power rating by using (1):

$$
\text { acceleration }=\mathrm{a}=\mathrm{F}_{\mathrm{ac}} / \mathrm{M}=\mathrm{dV} / \mathrm{dt}
$$

The acceleration force $F_{a c}$, is the force required to accelerate the eCAR during linear speed variations and is governed by Newton's second law as given in (2):

$$
\mathrm{F}_{\mathrm{ac}}=\mathrm{M} \times \mathrm{a}=\mathrm{MdV} / \mathrm{dt}
$$

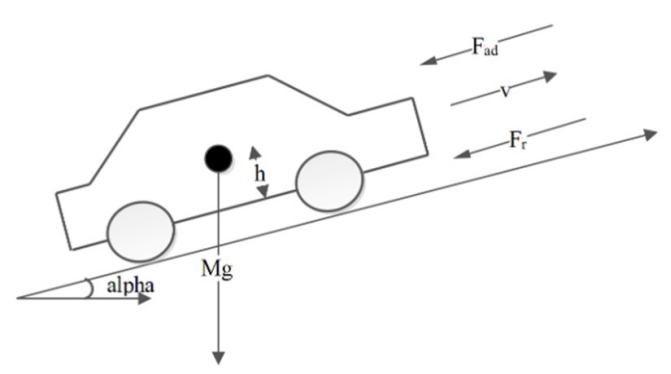

Fig. 2. eCAR and applied forces

The tractive effort needed to drive the eCAR in the forward direction neglecting vehicle dynamics is given by (3):

$$
\mathrm{F}_{\mathrm{t}}=\mathrm{F}_{\mathrm{ac}}=\mathrm{M} \times \mathrm{a}
$$

The friction of the eCAR wheels at the road surface is the only force existing at first. The coefficient of rolling friction $\mathrm{C}_{\mathrm{r}}$ between the tire and the road varies with the type and the size of the tire. The expression for rolling resistance is:

$$
\mathrm{F}_{\mathrm{r}}=\mathrm{C}_{\mathrm{r}} \times \mathrm{M} \times \mathrm{g} \text { for } \mathrm{V}=0,-\mathrm{C}_{\mathrm{r}} \times \mathrm{M} \times \mathrm{g} \text { for } \mathrm{V} \neq 0
$$

The aerodynamic drag is a function of speed and can be determined by the density of air $\mathrm{D}$ in $\mathrm{kg} / \mathrm{m}^{3}$, air drag coefficient $\mathrm{C}_{\mathrm{d}}$, vehicle frontal area $\mathrm{A}_{\mathrm{f}}$, and velocity $\mathrm{V}$. Thus, the aerodynamic drag force is:

$$
\mathrm{F}_{\mathrm{ad}}=1 / 2 \times \mathrm{D} \times \mathrm{C}_{\mathrm{d}} \times \mathrm{A}_{\mathrm{f}} \times \mathrm{V}^{2}
$$

The gradient force depends on $\mathrm{M}, \alpha$, and $\mathrm{g}$. The expression for this force is:

$$
\mathrm{F}_{\mathrm{g}}=\mathrm{M} \times \mathrm{g} \times \sin \alpha
$$

$\mathrm{F}_{\mathrm{r}}, \mathrm{F}_{\mathrm{ad}}$, and $\mathrm{F}_{\mathrm{g}}$ are summed up as road load $\mathrm{F}_{\mathrm{r}}$ :

$$
\mathrm{F}_{\mathrm{rl}}=\mathrm{F}_{\mathrm{r}}+\mathrm{F}_{\mathrm{ad}}+\mathrm{F}_{\mathrm{g}}
$$

Commonly, the tractive force $F_{t}$ to propel the eCAR has to surmount the sum of the rolling resistance force $F_{r}$, aerodynamic drag force $\mathrm{F}_{\mathrm{ad}}$, and hill climbing of gradient force $\mathrm{F}_{\mathrm{g}}$. And consequently, the total tractive effort is the summation of acceleration force and road load and is given by (8):

$$
\mathrm{F}_{\mathrm{t}}=\mathrm{F}_{\mathrm{ac}}+\mathrm{F}_{\mathrm{rl}}
$$

The velocity of the vehicle is calculated by integrating acceleration and is given by (9):

$$
\mathrm{V}=1 / \mathrm{M} \int\left(\mathrm{F}_{\mathrm{t}}-\mathrm{F}_{\mathrm{rl}}\right) \mathrm{dt}
$$

The time required to reach maximum speed and power rating of the motor are determined using (10), (11) and (12):

$$
\begin{gathered}
\mathrm{t}_{\mathrm{f}}=\mathrm{M} \int \mathrm{dV} / \mathrm{F}_{\mathrm{ac}}=\mathrm{M} \int \mathrm{dV} /\left(\mathrm{P}_{\text {motor }} / \mathrm{V}\right) \\
\mathrm{P}_{\text {motor }}=\mathrm{M} / \mathrm{t}_{\mathrm{f}} \int \mathrm{dv}=\mathrm{M} / 2 \mathrm{t}_{\mathrm{f}} \mathrm{V}^{2}
\end{gathered}
$$

or

$$
\begin{aligned}
& \mathrm{P}_{\text {motor }}=\mathrm{F}_{\mathrm{t}} \times \mathrm{V} \\
& \mathrm{E}_{\text {motor }}=\mathrm{P}_{\text {motor }} \times \mathrm{t}
\end{aligned}
$$

At first, the tractive effort required to propel the eCAR is found from (8). The product of tractive effort by the eCAR velocity gives the amount of power required and is found from (12). Assuming conversion efficiency factors, the energy required to propel is given in (13). To determine the optimum power size of the propulsion motor, a step by step procedure is presented in this paper and is as follows:

- Input speed and compute acceleration a using (1).

- Compute the value of acceleration force $\mathrm{F}_{\mathrm{ac}}$ for the given $\mathrm{M}$ using (2).

- Compute the amount of road load $F_{r l}$ using (7) by considering dynamics.

- Estimate total tractive force $F_{t}$ required by the propulsion using (8).

- Compute the value of maximum speed of an eCAR by (9).

- Measure and compare the actual speed of an eCAR with maximum speed. If the measured speed is equal to 
maximum speed then determine the value of motor power rating using (11) and end the process, else repeat the first step.

The output of the algorithm resolves the optimum power of the propulsion motor based on the maximum speed that an eCAR can manage.

\section{RANGE DETERMINATION}

To forecast the range of an eCAR, the energy essential to propel it at every instant of the drive cycle is to be calculated, and the effect of this energy trench to be observed. The eCAR range for varying mass $M$, gear ratio $G$, and air drag coefficient $\mathrm{C}_{\mathrm{d}}$, for Federal Urban Driving Schedule (FUDS), Simplified FUDS (SFUDS), European Urban Driving Schedule (EUDC) (ECE-47), and New European Drive Cycle (NEDC) are given in Table I. Note that the range is maximum when $M$ is $1200 \mathrm{~kg}$, gear ration is 10.8 and $C_{d}$ is 0.3 , which are considered the optimum values. This procedure is further continued with $90 \%$ depth of discharge of the battery. The effects of change in $\mathrm{M}$, $\mathrm{G}$, and $\mathrm{C}_{\mathrm{d}}$ for SFUDS cycle are depicted in Figures 3-5 respectively.

TABLE I. DRIVE CYCLES ACCOMPLISHED IN A SINGLE CHARGE

\begin{tabular}{|c|c|c|c|c|c|c|c|c|c|}
\hline \multirow{4}{*}{$\begin{array}{l}\text { Drive } \\
\text { cycle }\end{array}$} & \multicolumn{9}{|c|}{ Number of cycles } \\
\hline & \multicolumn{3}{|c|}{ Varying mass } & \multicolumn{3}{|c|}{ Varying G } & \multicolumn{3}{|c|}{ Varying $C_{d}$} \\
\hline & \multicolumn{3}{|c|}{$G=10.8, C_{d}=0.3$} & \multicolumn{3}{|c|}{$M=1200, C_{d}=0.3$} & \multicolumn{3}{|c|}{$M=1200, G=10.8$} \\
\hline & 1540 & 1320 & 1200 & 30 & 10.8 & 6.8 & 0.8 & 0.3 & 0.01 \\
\hline FUDS & 59 & 62 & 64 & 68 & 64 & 59 & 64 & 64 & 64 \\
\hline SFUDS & 241 & 254 & 260 & 270 & 260 & 245 & 260 & 260 & 261 \\
\hline ECE-47 & 112 & 139 & 156 & 208 & 156 & 101 & 153 & 156 & 159 \\
\hline NEDC & 100 & 120 & 134 & 166 & 134 & 95 & 132 & 134 & 135 \\
\hline
\end{tabular}

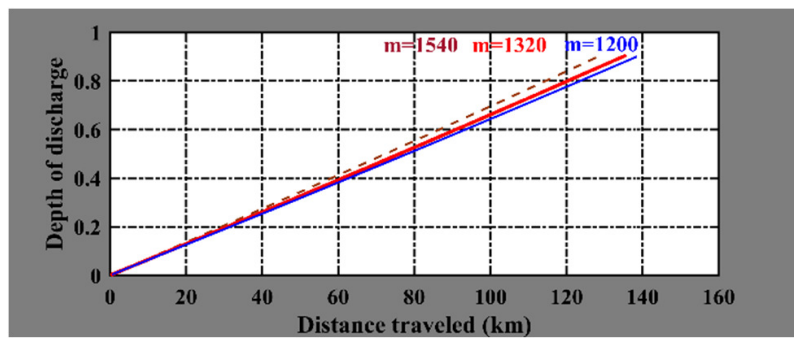

Fig. 3. Effect of varying mass on drive range

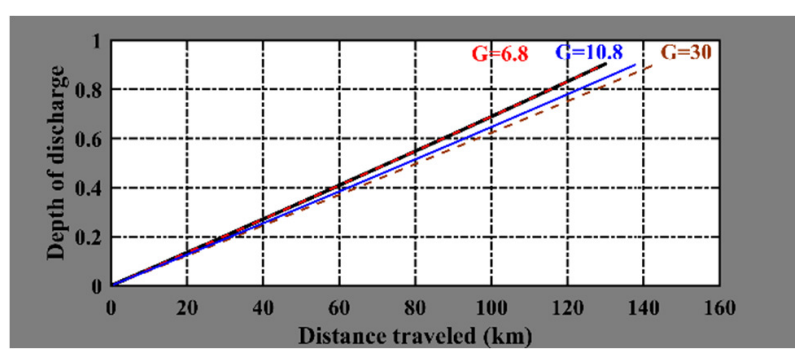

Fig. 4. Effect of varying gear ration on drive range

In a similar way, the range for different drive cycles is determined and tabulated in Table II. The specifications of an eCAR model considered for range determination are exhibited in Table III. From the data given in Table III, the acceleration time taken to drive the eCAR at a speed of $15 \mathrm{~m} / \mathrm{s}$ from start with different acceleration rates $\mathrm{a}=3.36 \mathrm{~m} / \mathrm{s}^{2}, \mathrm{a}=3.0 \mathrm{~m} / \mathrm{s}^{2}$ and $\mathrm{a}=2.26 \mathrm{~m} / \mathrm{s}^{2}$ is determined using (6) and gives $4.5 \mathrm{~s}, 5.1 \mathrm{~s}$, and 6.8 s respectively (Figure 6).

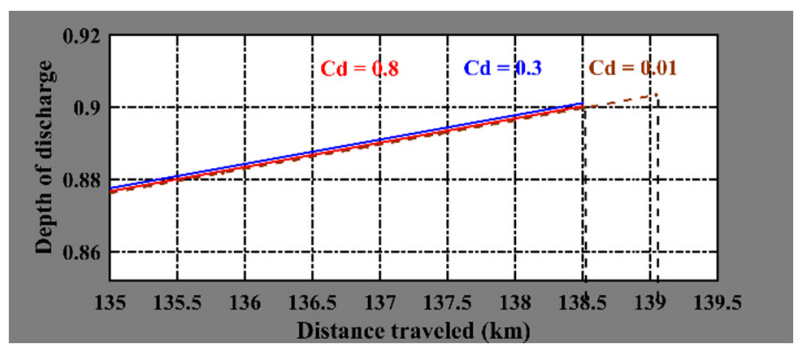

Fig. 5. Effect of varying $\mathrm{C}_{\mathrm{d}}$ on drive range

TABLE II. DRIVE RANGE IN A SINGLE CHARGE

\begin{tabular}{|c|c|c|c|c|c|c|c|c|c|}
\hline \multirow{4}{*}{$\begin{array}{l}\text { Drive } \\
\text { cycle }\end{array}$} & \multicolumn{9}{|c|}{ Distance travelled $(\mathrm{km})$ per charge } \\
\hline & \multirow{2}{*}{\multicolumn{3}{|c|}{$\begin{array}{l}\text { Varying mass, } \\
G=10.8, C_{d}=0.3\end{array}$}} & \multirow{2}{*}{\multicolumn{3}{|c|}{$\begin{array}{c}\text { Varying G, } \\
M=1200, C_{d}=0.3\end{array}$}} & \multirow{2}{*}{\multicolumn{3}{|c|}{$\begin{array}{c}\text { Varying } C_{d}, \\
M=1200, G=10.8\end{array}$}} \\
\hline & & & & & & & & & \\
\hline & 1540 & 1320 & 1200 & 30 & 10.8 & 6.8 & 0.8 & 0.3 & 0.01 \\
\hline FUDS & 120 & 126 & 130 & 138 & 130 & 120 & 130 & 130 & 130 \\
\hline SFUDS & 128 & 135 & 138 & 143 & 138 & 130 & 138 & 138 & 139 \\
\hline ECE-47 & 110 & 137 & 154 & 206 & 154 & 99 & 151 & 154 & 157 \\
\hline NEDC & 100 & 120 & 134 & 166 & 134 & 95 & 132 & 134 & 134 \\
\hline
\end{tabular}

TABLE III. ECAR SPECIFICATIONS

\begin{tabular}{|l|c|}
\hline Mass of the vehicle, $\mathbf{M}$ & $1200 \mathrm{Kg}$ \\
\hline Frontal Area of the vehicle, $\mathbf{A}_{\mathbf{f}}$ & $0.2 \mathrm{sq} . \mathrm{mt}$ \\
\hline Wheel radius, $\mathbf{R}_{\mathbf{w}}$ & $0.2794 \mathrm{~m}$ \\
\hline Coefficient of Rolling resistance, $\mathbf{C}_{\mathbf{r}}$ & 0.0015 \\
\hline Air Density, D & $1.225 \mathrm{Kg} / \mathrm{m} 3$ \\
\hline Air drag coefficient, $\mathbf{C}_{\mathbf{d}}$ & 0.3 \\
\hline Gravitational constant, $\mathbf{g}$ & $9.81 \mathrm{Kg} / \mathrm{m} 2$ \\
\hline Transmission gear ratio, $\mathbf{G}$ & 10.8 \\
\hline Slope or gradient angle, $\boldsymbol{\alpha}$ & $5 \mathrm{o}$ \\
\hline
\end{tabular}

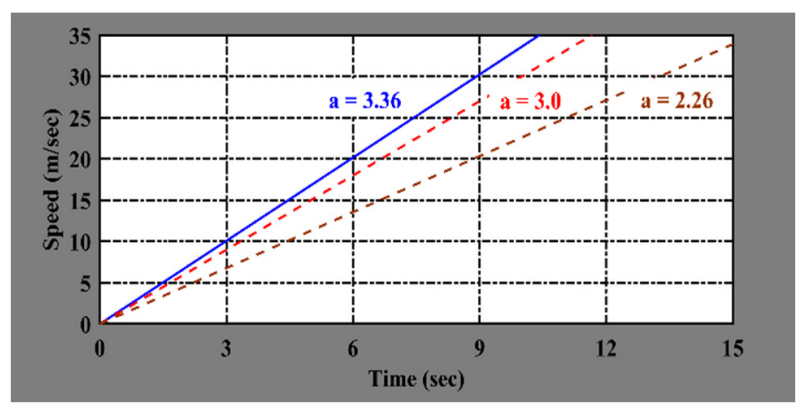

Fig. 6. Acceleration performance of an eCAR

As acceleration increases the time required to reach the desired speed decreases. Higher acceleration demands more tractive force which increases the required power of the motor. For given mass and fixed acceleration of $3.36 \mathrm{~m} / \mathrm{s}^{2}$ the power required to propel the eCAR to a maximum speed of $120 \mathrm{~km} / \mathrm{h}$ from zero speed is determined using (16). At zero road load condition the thick line curve shown in Figure 7, depicts that a $90 \mathrm{~kW}$ motor takes about $14 \mathrm{~s}$ to propel the eCAR and a $30 \mathrm{~kW}$ motor takes about $35 \mathrm{~s}$. Considering road load the dotted curve illustrates that a $30 \mathrm{~kW}$ motor takes $60 \mathrm{~s}$ and a $90 \mathrm{~kW}$ motor requires 14 s (Figure 8). 


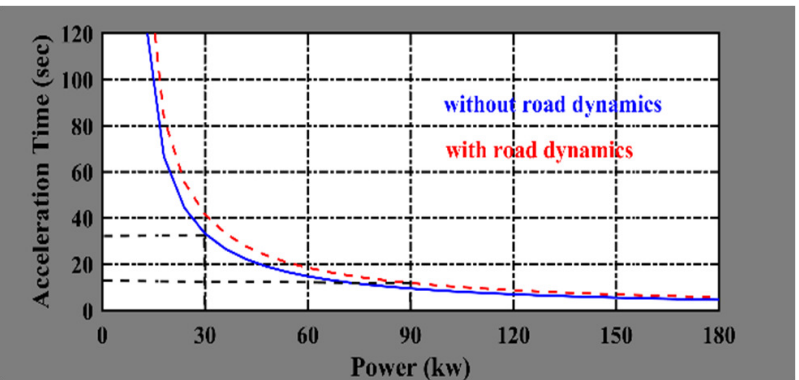

Fig. 7. Propulsion motor power requirement vs acceleration time

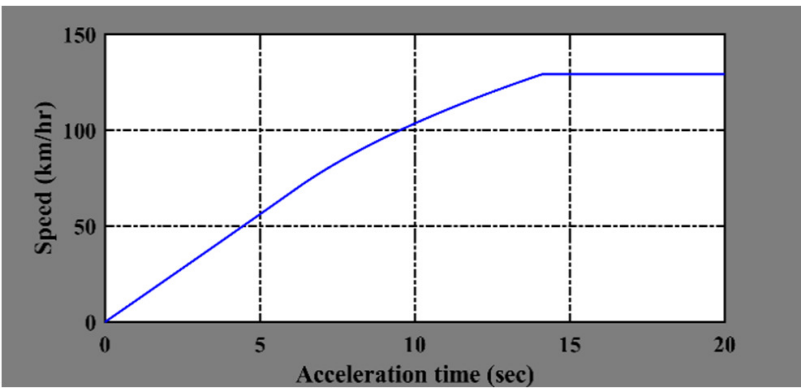

Fig. 8. Full power acceleration of a $90 \mathrm{~kW}$ motor

To reach $120 \mathrm{~km} / \mathrm{hr}$ speed with a tractive force of $1127 \mathrm{Nm}$ the power of the motor needed is computed from (17) and is $88.9 \mathrm{~kW}$ which is approximately $90 \mathrm{~kW}$. Based on the derived conclusions, it is decided that the optimum power of the motor to drive an eCAR is $90 \mathrm{~kW}$. The specifications of considered optimum propulsion motor of an eCAR are given in Table IV.

TABLE IV. SPECIFICATIONS OF A 90KW INDUCTION MOTOR

\begin{tabular}{|l|c|}
\hline \multicolumn{2}{|c|}{ 3Ф, AC Induction motor } \\
\hline Motor Power rating, $\mathbf{P}_{\text {motor }}$ & $90 \mathrm{~kW}$ \\
\hline Nominal voltage, $\mathbf{V}_{\mathbf{n}}$ & $380 \mathrm{~V}, \mathrm{RMS}$ \\
\hline Current rating, $\mathbf{I}_{\mathbf{n}}$ & $200 \mathrm{~A}$ \\
\hline Variable frequency, $\mathbf{f}_{\mathbf{s}}$ & $0-400 \mathrm{~Hz}$ \\
\hline Constant power & $90 \mathrm{~kW} @ 12000 \mathrm{rpm}$ \\
\hline Constant torque & $120 \mathrm{Nm} @ 7200 \mathrm{rpm}$ \\
\hline Motor inertia, $\mathbf{J}_{\text {motor }}$ & $1.5 \mathrm{kgm}^{2}$ \\
\hline Pole pairs, $\mathbf{p}$ & 2 \\
\hline Nominal stator flux, $\boldsymbol{\psi}_{\mathbf{s}}$ & $0.98 \mathrm{~Wb}$ \\
\hline
\end{tabular}

The MATLAB Simulink model of the electric propulsion system of an eCAR is shown in Figure 9. The subsystem of the Simulink model representing the applied vehicle dynamics is shown in Figure 10 where constants $\mathrm{A}=72.84, \mathrm{~B}=0.0384$, and $\mathrm{C}=0.32$ represent the rolling friction coefficient, the gradient, and the aerodynamic drag coefficient respectively. The torquespeed curves for the optimized three phase induction motor as eCAR propulsion motor are shown in Figure 11. The torque versus time characteristics for the $90 \mathrm{~kW}$ motor with varying gear ratio $G$ are shown in Figure 12. The power versus time characteristics for the $90 \mathrm{~kW}$ motor with varying gear ratio $\mathrm{G}$ are shown in Figure 13. The velocity curves for different gear ratios for the $90 \mathrm{~kW}$ induction motor as a propulsion motor of an eCAR are shown in Figure 14.

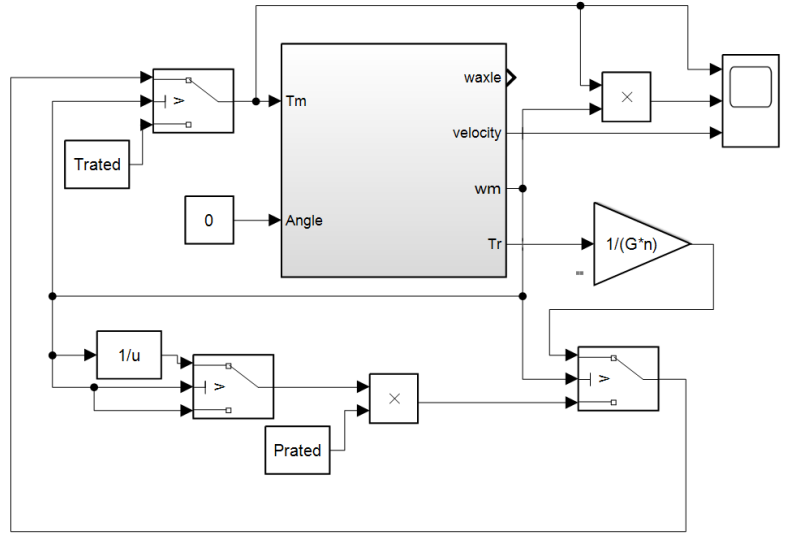

Fig. 9. Simulink model of the eCAR

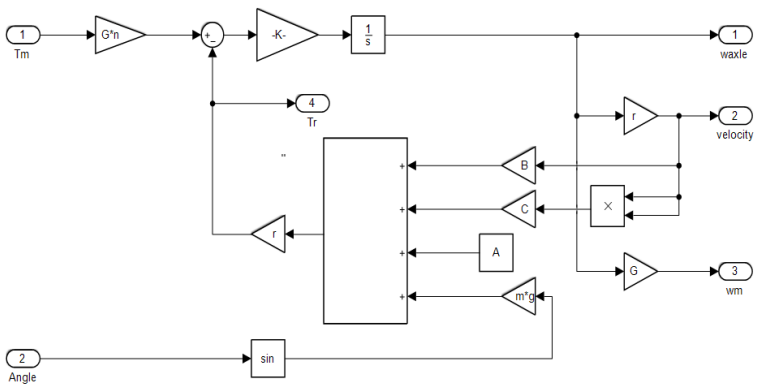

Fig. 10. The subsystem of the eCAR model

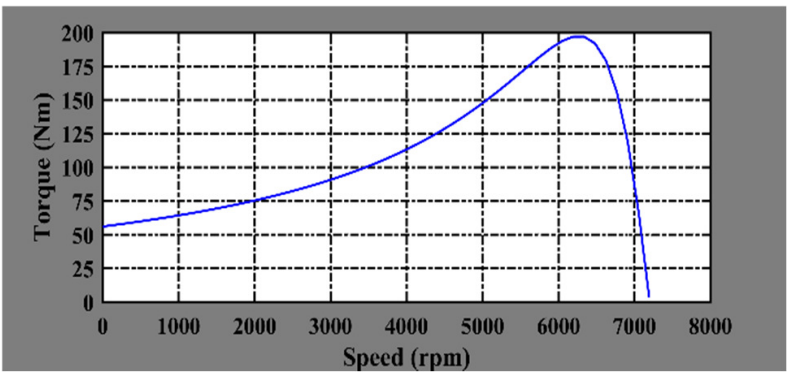

Fig. 11. Torque-speed characteristic for the $90 \mathrm{~kW}$ induction motor

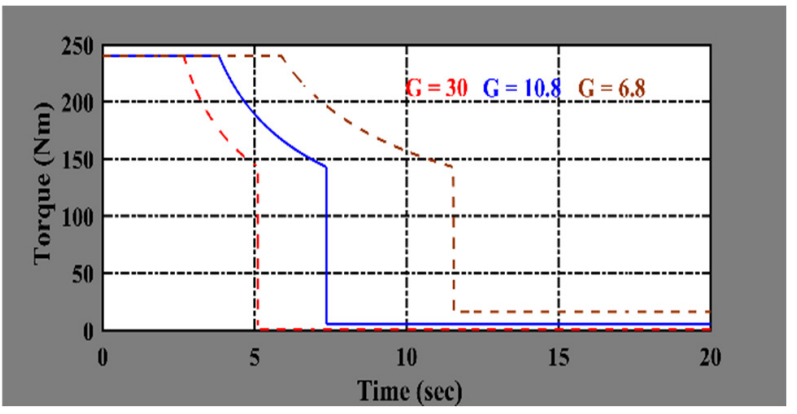

Fig. 12. Torque characteristics with varying $\mathrm{G}$

The change in $G$ predominantly affects the performance characteristics of the propulsion motor, a high $\mathrm{G}$ is required to operate the motor in constant power but limits the maximum speed of the vehicle. Hence, an optimal value of 10.8 gear ratio is chosen for the drive train of an eCAR, with propulsion motor 
operating in filed weakening mode, this can be achieved with the help of field oriented control or direct torque control techniques [21-23].

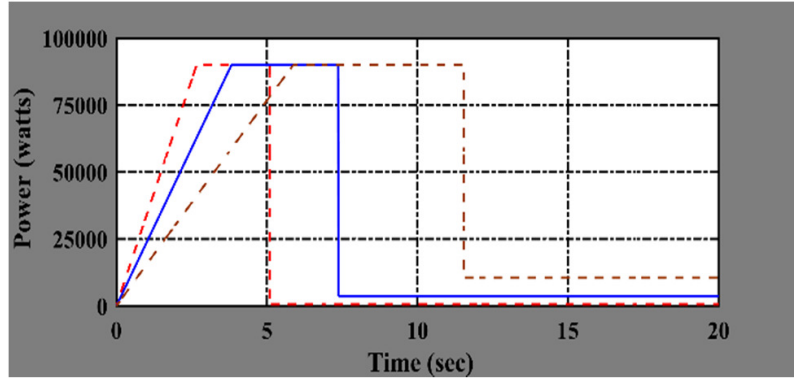

Fig. 13. Power characteristics with varying $\mathrm{G}$

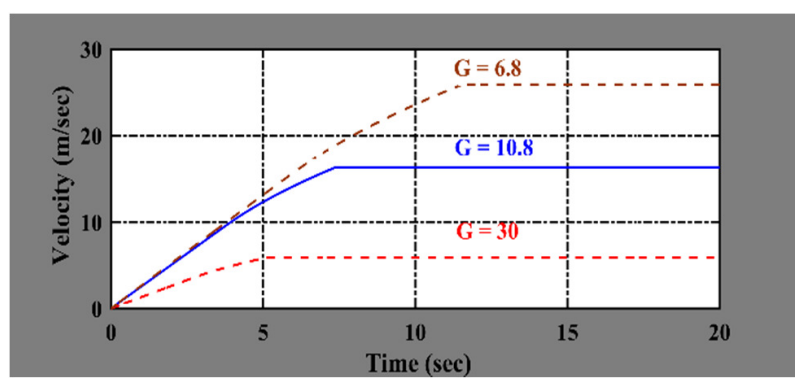

Fig. 14. Velocity of an eCAR with varying $\mathrm{G}$

\section{CONCLUSIONS}

A method for performance optimization of an eCAR based on vehicle parameters is examined considering the impact of road dynamics, acceleration rate, change in mass and gear ratio of an eCAR. The output of the proposed algorithm resolves the optimum power size of the propulsion motor based on the maximum speed and is derived as $90 \mathrm{~kW}$. From the acceleration characteristics, a $90 \mathrm{~kW}$ motor may suffice the required tractive force to propel the eCAR, attaining a speed of $120 \mathrm{~km} / \mathrm{h}$ in $14 \mathrm{~s}$ with an acceleration of $2.38 \mathrm{~m} / \mathrm{s}^{2}$, which meets the customer's needs. The eCAR propulsion motor counting road dynamics is modeled with the help of mathematical relations. The performance characteristics of the $90 \mathrm{~kW}$ induction motor for different gear ratios were obtained. It is seen that for higher gear ratios the maximum speed attained by the vehicle decreases, therefore a gear ratio of 10.8 is considered as optimum for the eCAR. The proposed optimization technique is simple, efficient and can be applied on any configuration of the eCAR.

\section{REFERENCES}

[1] F. Faisal, "An analysis of electric vehicle trends in developed nations: a sustainable solution for India", Journal of Undergraduate Research, Vol. 9, No. 1-5, pp. 1-8, 2017

[2] I. Lingvay, A. Bors, D. Lingvay, "Considerations about the local and global environmental impact of autonomy electric transport", Electric Vehicles International Conference, Bucharest, Romania, October 5-6, 2017

[3] E. Figenbaum, C. Weber, "Estimating real-world emissions of PHEVs in Norway by combining laboratory measurement with user surveys", World Electric Vehicle Journal, Vol. 9, No. 2, Article ID 31, 2018
[4] C. Mazur, M. Contestabile, J. G. Offer, N. P. Brandon, "Understanding the automotive industry: German OEM behaviour during the last 20 years and its implications", World Electric Vehicle Journal, Vol 6, No. 4, pp. 1054-1067, 2013

[5] A. R. Salisa, N. Zhang, J. G. Zhu, "A comparison on fuel economy and emissions for conventional hybrid electric vehicles and the UTS plug-in hybrid electric vehicle", IEEE Transactions on Vehicular Technology, Vol. 60, No. 1, pp. 44-54, 2011

[6] M. De Gennaro, E. Paffumi, H. Scholz, G. Martini, "Analysis and assessment of the electrification of urban road transport based on reallife mobility data", World Electric Vehicle Symposium and Exhibition, Barcelona, Spain, November 17-20, 2013

[7] K. L. Mokariya, V. A Shah, M. M. Lokhande, "Impact of penetration of electric vehicles on Indian power grid", World Electric Vehicle Journal, Vol. 7, No. 4, pp. 518-529, 2015

[8] K. Scholz-Starke, A. Fortino, J. Hammer, "City buses with alternative power trains under realistic driving conditions", World Electric Vehicle Journal, Vol. 8, No. 1, pp. 139-150, 2016

[9] J. Wang, I. Besselink, H. Nijmeijer, "Online prediction of battery electric vehicle energy consumption”, EVS29 International Battery, Hybrid and Fuel Cell Electric Vehicle Symposium, Montreal, Canada, June 19-22, 2016

[10] E. Wilhelm, R. Bornatico, R. Widmer, L. Rodgers, G. S. Soh, "Electric vehicle parameter identification", World Electric Vehicle Journal, Vol. 5, No. 4, pp. 1090-1099, 2012

[11] H. Jung, R. Silva, M. Han, "Scaling trends of electric vehicle performance: driving range, fuel economy, peak power output, and temperature effect", World Electric Vehicle Journal, Vol. 9, No. 4, pp. 46-59, 2018

[12] R. Vijayagopal, R. Chen, P. Sharer, S. M. Wild, A. Rousseau, "Using multiobjective optimization for automotive component sizing", World Electric Vehicle Journal, Vol. 7, No. 2, pp. 261-269, 2015

[13] S. Chakraborty, H. N. Vu, M. M. Hasan, D. D. Tran, M. El Baghdadi, O. Hegazy, "DC-DC converter topologies for electric vehicles, plug-in hybrid electric vehicles and fast charging stations: state of the art and future trends", Energies, Vol. 12, No. 8, Article ID 1569, 2019

[14] L. Pan, C. Zhang, "An integrated multifunctional bidirectional AC/DC and DC/DC converter for electric vehicles applications", Energies, Vol. 9, No. 7, Article ID 493, 2019

[15] M. J. Safoutin, J. McDonald, B. Ellies, "Predicting the future manufacturing cost of batteries for plug-in vehicles for the U.S. Environmental Protection Agency (EPA) 2017-2025 light-duty greenhouse gas standards", World Electric Vehicle Journal, Vol. 9, No. 3, Article ID 42, 2018

[16] A. Loiselle-Lapointe, I. Whittal, M. Christenson, "Electric vehicles: impacts of mileage accumulation and fast charging", World Electric Vehicle Journal, Vol. 8, No. 1, pp. 249-262, 2016

[17] I. Bolvashenkov, J. Kammermann, H. Herzog, "Methodology for selecting electric traction motors and its application to vehicle propulsion systems", International Symposium on Power Electronics, Electrical Drives, Automation and Motion, Anacapri, Italy, June 22-24, 2016

[18] S. Jurkovic, K. M. Rahman, P. J. Savagian, "Design, optimization and development of electric machine for traction application in GM battery electric vehicle", IEEE International Electric Machines \& Drives Conference (IEMDC), Coeur d'Alene, USA, May 10-13, 2015

[19] M. Pfriem, F. Gauterin, "Development of real-world driving cycles for battery electric vehicles", World Electric Vehicle Journal, Vol. 8, No. 1, pp. 12-24, 2016

[20] V. Parekh, V. Shah, "Measurement and analysis of Indian road drive cycles for efficient and economic design of HEV component", World Electric Vehicle Journal, Vol. 7, No. 1, pp. 121-132, 2015

[21] H. Aygun, M. Aktas, "A novel DTC method with efficiency improvement of IM for EV applications", Engineering, Technology \& Applied Science Research, Vol. 8, No. 5, pp. 3456-3462, 2018

[22] P. R. Tripathy, B. P. Panigrahi, "Study of direct torque controlled 3phase SCIM with two and three-level inverters using ST-DTC and FR- 
DTC scheme", Engineering, Technology \& Applied Science Research, Vol. 5, No. 1, pp. 748-752, 2015

[23] O. M. Al-Barbarawi, "Improving performance of the braking process, and analysis torque-speed characteristics of the induction motor", Engineering, Technology \& Applied Science Research, Vol. 8, No. 6, pp. $3585-3591,2018$

\section{AUTHORS PROFILE}

Banda Gururaj was born in 1987. He received his BTech degree from Jawaharlal Nehru Technological University Hyderabad, India in 2008 and his MTech degree in Power Electronics from Sri Krishna Devaraya University, Anantapur, India in 2011. At present he is pursuing his $\mathrm{PhD}$, at R\& D Center, GPREC, Kurnool, Department of Electrical and Electronics Engineering, Jawaharlal Nehru Technological University Anantapur, Ananthapuramu, Andhra Pradesh, India. He has 10 years of teaching experience and has published 4 papers in reputed journals, 2 international conference papers, and 4 national conference papers. His areas of interest are Electric and Hybrid Electric Vehicle technology, Power Electronics and Drives, Control Systems and Artificial Intelligence.

K. Sri Gowri was born in 1974. She received her BTech degree from Sri Venkateswara University College of Engineering, Tirupati, India, in 1996, her MTech degree in Power Electronics from Jawaharlal Nehru Technological University, Hyderabad, India, in 2005, and her $\mathrm{PhD}$ degree from the Jawaharlal Nehru Technological University, Kakinada, India in 2011. She is presently working as a Professor in the Department of Electrical and Electronics Engineering at G Pulla Reddy Engineering College, Kurnool, India. She has published 40 research papers in national and international conferences and journals. Her current research interest include Power Electronic Converters, PWM Techniques, AC Drives and Control. 